\title{
ABSENCE OF ZONATION IN A MANGROVE FOREST IN SOUTHEASTERN BRAZIL
}

\author{
João Marcos Miragaia Schmiegelow ${ }^{1}$ and Sônia Maria Flores Gianesella ${ }^{2}$ \\ ${ }^{1}$ Universidade Santa Cecília \\ (Rua Oswaldo Cruz, 277, 11045-907 Santos, SP, Brasil) \\ ${ }^{2}$ Instituto Oceanográfico da Universidade de São Paulo \\ (Praça do Oceanográfico, 191, 05508-120 São Paulo, SP, Brasil)
}

*Corresponding author: miragaiaunisanta@yahoo.com.br

http://dx.doi.org/10.1590/S1679-87592014058806202

\begin{abstract}
A B S TR ACT
The mangrove forest of the estuarine system of Santos, Brazil, occupies $71 \mathrm{~km}^{2}$ - an area consisting of a complex system of canals and rivers forming a predominantly depositional environment. The climate provides high rainfall, with no water deficit and minimum temperatures above $18^{\circ} \mathrm{C}$. In this environment, 3,870 mangrove trees, distributed on 20 random transects, were identified, counted and measured and the litterfall measured. The phytosociological data (density, height and basal area) were measured in parcels at different distances from the waterline. Three species of trees were identified: Rhizophora mangle, Avicennia schaueriana and Laguncularia racemosa. The data showed large variability between stands but with no zonation perpendicular to the fringe in relation to phytosociological descriptors, the distribution of the tree species and litterfall production. This phenomenon is attributed to the low energy subsidy occurring as a function of the microtidal regime, the reduced velocity of the water in the innermost regions of the estuarine system, the homogeneous sediment (silt) and mostly the absence of any water deficit in the region. All these factors reduce the environmental gradient from the fringe to the interior of the basin. Some stands also showed immature features which were attributed to the anthropogenic impacts of many kinds, mainly over the last 60 years, that have been preventing the mangroves from attaining their full development.
\end{abstract}

\section{RESUMO}

O manguezal do sistema estuarino de Santos, Brasil, ocupa uma área de $71 \mathrm{~km}^{2}$, consistindo de um complexo sistema de canais e rios, em ambiente predominantemente deposicional. O clima apresenta alta pluviosidade, sem déficit hídrico e com temperatura mínima de $18^{\circ} \mathrm{C}$. Foram mensuradas, contadas e identificadas 3.870 árvores de mangue em 20 seções aleatórias e medida a produção mensal de serapilheira. Os dados fitossociológicos (densidade, altura e área basal) foram medidos em parcelas a diferentes distâncias da linha da água. Três espécies de árvores foram identificadas: Rhizophora mangle, Avicennia schaueriana e Laguncularia racemosa. Os dados mostraram grande variabilidade entre bosques, mas sem zonação perpendicular à franja, em relação a todas as variáveis fitossociológicas, à distribuição das espécies arbóreas e à produção de serapilheira. Atribuiu-se este fenômeno ao baixo subsídio de energia devido ao regime de micromarés, à reduzida velocidade da água nas regiões internas do sistema estuarino, à homogeneidade do sedimento (silte), e, principalmente, à ausência de déficit hídrico na região. Todos estes fatores reduzem o gradiente ambiental da franja para a bacia. Alguns bosques apresentaram feições de imaturidade o que foi atribuído aos impactos antropogênicos de diversas naturezas, principalmente nos últimos 60 anos, que estariam obstando o pleno desenvolvimento do manguezal.

Descriptors: Mangrove structure, Phytosociology, Zonation, Litterfall, Santos estuarine system. Descritores: Estrutura de manguezal, Fitossociologia, Zonação, Serapilheira, Sistema estuarino de Santos.

\section{INTRODUCTION}

Structural characterization of mangrove forests is a valuable tool for evaluating the ecosystem's response to environmental conditions, as well as the processes of environmental change (CINTRÓN AND SCHAEFFER-NOVELLI, 1985). The architecture of these forests is the result of the interaction between the growth characteristics of trees, their physiological requirements and the 
environmental forcings that affect the system. The mangrove forest structure is also the outcome of optimal selection and the competitive abilities of each plant species of the ecosystem (BALL, 1980; SNEDAKER, 1982).

Established mangrove areas have clear environmental gradients due to, among other things, tide variation, which together with other factors shape mangrove structure and production. As a result, a common feature of mangrove systems is the zonation in the structure, production and distribution of the species in relation to their distance from the water. The synthesis devised by CHAPMAN (1975) describing the zonation of mangroves, led to the zonation paradigm as a worldwide mangrove benchmark. SNEDAKER (1982) also emphasizes that the preeminent feature of a mangrove forest structure is often the conspicuous zonation of tree species in monospecific bands parallel to the shoreline.

Along the coastal region of the western South Atlantic, mangroves occur only on the Brazilian coast, reaching a latitude of $28^{\circ} 30^{\prime} \mathrm{S}$ (ScHAEFFER-NOVELLI, 1989). One of the most striking characteristics of New World mangroves is their low diversity, yet, despite their deceptive apparent simplicity, New World mangrove species are extraordinarily plastic in adapting to their environment (SCHAEFFER-NOVELLI et al., 2000). The wide latitudinal variation of the Brazilian coast $\left(5^{\circ} 16^{\prime} \mathrm{N}\right.$ to $\left.33^{\circ} 45^{\prime} \mathrm{S}\right)$ and consequently of precipitation, tidal height and temperatures result in a large variation in the structure of mangrove forests at the level of coastal domains (SCHAEFFER-NOVELLI et al., op. cit.). On the other hand, according to these authors, for the levels of "Setting" (representing the extensions of 10 to $\left.100 \mathrm{~km}^{2}\right)$, "Stands" (0.1 to $\left.100 \mathrm{ha}\right)$ and "Sites" (which correspond to the plot or tree, of between 0.01 and $0.1 \mathrm{ha}$ ), other factors such as salinity and edaphic factors, soil nutrients, frequency of floods, winds and storm intensity, biotic factors and others, are more important.

Several authors have studied the mangrove forests of the estuarine system of Santos (São Paulo, Brazil), but according to SCHMIEGELOW et al. (2008) who listed these studies, only a few of them were actually published and, in general, they only considered small mangrove areas: MENEZES et al. (2005) planted propagules of Rhizofora mangle and germinated seeds of Laguncularia racemosa, and MENGHINI et al. (2011) studied the recovery of a small area (Barnabé Island) affected by fire due to the accidental spillage of an inflammable chemical (DCPD-dicyclopentadiene).

On the other hand, the State environmental agency (CETESB, 1988), about 30 years ago (between 1982 and 1984), conducted a broad survey of an area to evaluate the phytosociology of the mangrove fringe. At that time the region suffered severe and frequent industrial impacts. In the early 1990s, the region still suffered from oil spills, which affected some mangrove areas (mainly the Bertioga channel), and other events such as the dumping of industrial pollutants.

The original marsh was severely impacted by urban occupation, especially the port and an industrial park in the innermost region, near the municipality of Cubatão. In the 1970s, this particular area was considered one of the most polluted in the world (LEMOS, 1998), however, it has undergone intense monitoring and control in recent decades. Even so, the region is entering a new period of economic development as a consequence of recent oil exploitation of the socalled pré-sal reserves. As a result, the wetlands are again under pressure from plans to extend the area available for port expansion as well as to deal with the pollution due to possible oil spills and other industrial waste discharges.

Given the ecological and strategic importance of this ecosystem and the need for adequate information to ensure its proper environmental management, especially in the face of the new threats, the present study was undertaken to provide information on the phytosociology of the mangroves of the estuarine system of Santos as well as quantitative data on the production of litter, in terms of the water gradient.

\section{Material And Methods}

\section{Location}

The Santos estuarine system (Fig. 1), classified by Pritchard (PRITCHARD, 1967) as a coastal estuary plain, is situated around $24^{\circ} \mathrm{S}$ and $46^{\circ} 25^{\prime} \mathrm{W}$. Its current configuration has resulted from successive sea transgressions and regressions which occurred during the Quaternary period. In the last transgressive phase (Santos transgression), 5100 years BP, the channels, formed by erosion during a previous regression, were filled by the sea, which deposited clay sediments on the sandy deposits below, forming the current lagoon system (MARTIN AND SUGUIO, 1989). This rise led to the formation of a complex system of channels and rivers of different sizes whose banks were occupied by mangroves during the return of the sea to its current level. Currently, about $71 \mathrm{~km}^{2}$ of mangrove forests are to be found in the entire estuarine region (SCHMIEGELOW et al., 2008). The complex geomorphology of the area, with eight drainage basins and an increasing rainfall gradient from the 
sea towards the Serra do Mar, promotes an extremely varied water regime throughout the channels, both in terms of salinity, nutrients, frequency of flooding by tides and potential for dilution of the pollutants. The climate is classified as of the Af type. The annual mean precipitation is 3,207mm (EMBRAPA, 2012), January to March (the austral summer) being the period of heaviest rainfall and July to August (winter) of the least. The average temperature is $23.5^{\circ} \mathrm{C}$ (TUTIEMPO, 2010 from 2006 to 2010), and the lowest monthly temperature is $\geq 18^{\circ} \mathrm{C}$ (SANTOS, 1965). Tides are asymmetrical with semi-diurnal amplitudes of 0.60 $\mathrm{m}$ at the spring tide and $0.14 \mathrm{~m}$ at the neap (HARARI AND CAMARGO, 1995). The subbasins flowing into the estuary have an average flow of less than $40.4 \mathrm{~m}^{3} \mathrm{~s}^{-1}$ (CETEC, 2000).

The geomorphological characteristics of the Santos Estuary, forming a long, deep channel (the Santos Channel), were ideal for establishing a harbor in the region. Today it is the most active and largest port in Latin America. In the surroundings of the innermost area of the estuary is the Cubatão industrial hub, which is the main source of the chemical pollutants discharged into the estuary and the adjacent marine environment, in view of the diversity and quantity of the current effluents and the already existing contamination (CETESB, 2001).

\section{Methodology}

The study area covered $31.6 \mathrm{~km}^{2}$ of mangrove forest mainly skirting São Vicente Island, in the continental portion of the estuary. A total of 20 transects were randomly selected in the study area in zones defined by the presence of larger watercourses (Fig. 1). The transects started at the waterline always being perpendicular to it (Fig. 1), their length varying between 117 and $280 \mathrm{~m}$ according to the characteristics of each region, always stretching out towards the edge of the forest, and were named according to the main local toponym (Table 1).

Four sites were established along each transect: one at the water's edge (named "edge"), one at the extremity distal from the water ("landward") and the other two, at one-third ("lower middle") and two-thirds of the total length ("upper middle") as from the mean tidal level. Centered on each site, parcels of $100 \mathrm{~m}^{2}(10 \mathrm{~m} \times 10 \mathrm{~m})$ were established.

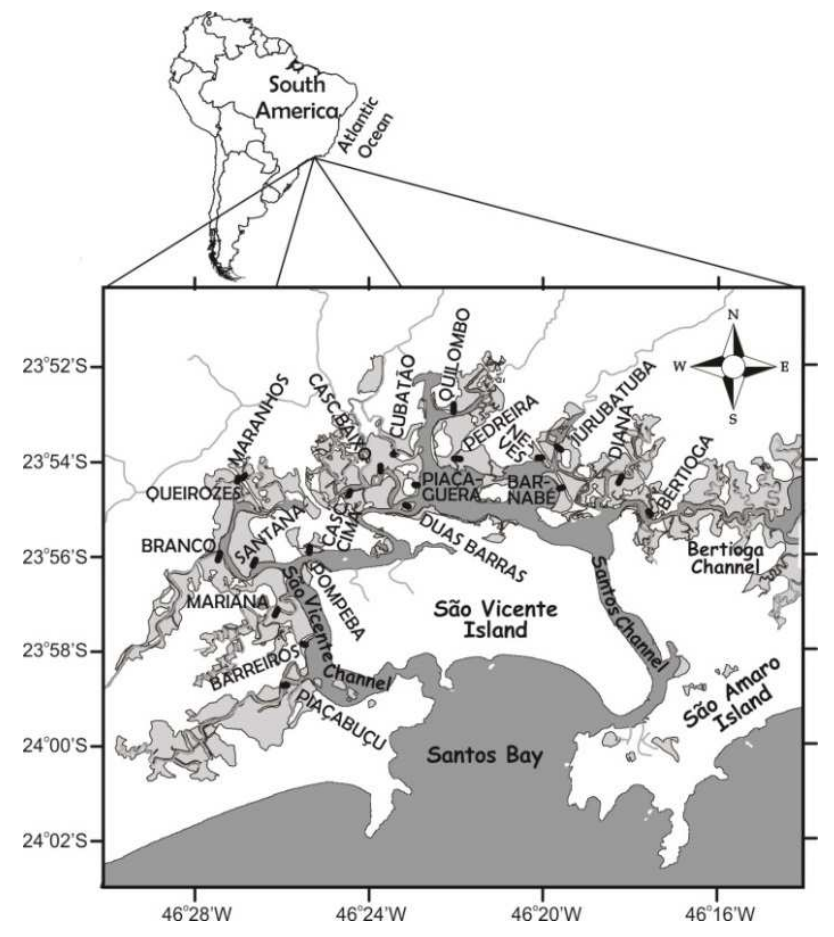

Fig. 1. Study area. Land is shown in white, water (ocean and continental water) in gray and mangrove forests in light gray; black lines represent the transects. 
Table 1. Local and stand name, length and geographical location of transects. *Stands for which grain size data were collected.

\begin{tabular}{|c|c|c|c|c|}
\hline LOCAL NAME & STAND NAME & $\begin{array}{l}\text { TRANSECT } \\
\text { LENGTH }(\mathrm{m})\end{array}$ & SITE & $\begin{array}{l}\text { TRANSECT GEOGRAPHICAL } \\
\text { LOCATION*** }\end{array}$ \\
\hline \multirow{2}{*}{ Bertioga Channel } & \multirow{2}{*}{ Bertioga } & \multirow{2}{*}{159} & 1 & $23^{\circ} 55^{\prime} 10.9^{\prime \prime S} 46^{\circ} 17^{\prime} 31.3^{\prime \prime} \mathrm{W}$ \\
\hline & & & 4 & $23^{\circ} 54^{\prime} 39.2^{\prime \prime} \mathrm{S} 46^{\circ} 19^{\prime} 29.1$ 'W \\
\hline \multirow{2}{*}{ Diana River } & \multirow{2}{*}{ Diana* } & \multirow{2}{*}{280} & 1 & $23^{\circ} 54^{\prime} 13.9^{\prime \prime S} 46^{\circ} 17^{\prime} 58.0^{\prime \prime} \mathrm{W}$ \\
\hline & & & 4 & $23^{\circ} 54^{\prime} 34.2^{\prime \prime} \mathrm{S} 46^{\circ} 18^{\prime} 12.5^{\prime}, \mathrm{W}$ \\
\hline \multirow{2}{*}{ Jurubatuba River } & \multirow{2}{*}{ Jurubatuba } & \multirow{2}{*}{215} & 1 & $23^{\circ} 53^{\prime} 47.4^{\prime \prime S} 46^{\circ} 19^{\prime} 36.9^{\prime \prime W}$ \\
\hline & & & 4 & 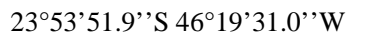 \\
\hline \multirow{2}{*}{ Barnabé Island } & \multirow{2}{*}{ Barnabé* } & \multirow{2}{*}{153} & 1 & $23^{\circ} 54^{\prime} 40.5^{\prime \prime S} 46^{\circ} 19^{\prime} 34.3^{\prime \prime} \mathrm{W}$ \\
\hline & & & 4 & $23^{\circ} 54^{\prime} 39.2^{\prime \prime} \mathrm{S} 46^{\circ} 19^{\prime} 29.1^{\prime \prime} \mathrm{W}$ \\
\hline \multirow{2}{*}{ Nossa Senhora das Neves Stream } & \multirow{2}{*}{ Neves* } & \multirow{2}{*}{172} & 1 & $23^{\circ} 54^{\prime} 01.9^{\prime \prime S} 46^{\circ} 19^{\prime} 58.2^{\prime \prime W}$ \\
\hline & & & 4 & $23^{\circ} 54^{\prime} 01.0^{\prime} \prime \mathrm{S} 46^{\circ} 20^{\prime} 03.5^{\prime \prime} \mathrm{W}$ \\
\hline \multirow{2}{*}{ Quilombo River } & \multirow{2}{*}{ Quilombo* } & \multirow{2}{*}{282} & 1 & 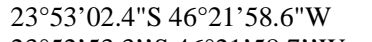 \\
\hline & & & 4 & $23^{\circ} 52^{\prime} 53.3^{\prime \prime} \mathrm{S} 46^{\circ} 21^{\prime} 58.7^{\prime \prime} \mathrm{W}$ \\
\hline \multirow{2}{*}{ Piaçaguera Channel } & \multirow{2}{*}{ Piaçaguera* } & \multirow{2}{*}{117} & 1 & $23^{\circ} 54^{\prime} 34.7^{\prime \prime S} 46^{\circ} 22^{\prime} 49.4^{\prime \prime} \mathrm{W}$ \\
\hline & & & 4 & $23^{\circ} 54^{\prime} 34 .^{\prime \prime} \mathrm{S} 46^{\circ} 22^{\prime} 53.5^{\prime \prime} \mathrm{W}$ \\
\hline \multirow{2}{*}{ Pedreira River } & \multirow{2}{*}{ Pedreira* } & \multirow{2}{*}{250} & 1 & $23^{\circ} 54^{\prime} 01.5^{\prime \prime S} 46^{\circ} 21^{\prime} 59.0^{\prime \prime} \mathrm{W}$ \\
\hline & & & 4 & $23^{\circ} 54^{\prime} 02.0^{\prime \prime} \mathrm{S} 46^{\circ} 21^{\prime} 50.2^{\prime \prime} \mathrm{W}$ \\
\hline \multirow{2}{*}{ Duas Barras Island } & \multirow{2}{*}{ Duas Barras } & 153 & 1 & $23^{\circ} 54^{\prime} 59.6^{\prime \prime S} 46^{\circ} 23^{\prime} 06.5^{\prime \prime W}$ \\
\hline & & 153 & 4 & $23^{\circ} 55^{\prime} 02.2^{\prime \prime} \mathrm{S} 46^{\circ} 23^{\prime} 01.9^{\prime}$ 'W \\
\hline Cubatão River & Cubatão & 152 & 1 & $23^{\circ} 53^{\prime} 51.9^{\prime \prime S} 46^{\circ} 23^{\prime} 19.1$ "W \\
\hline & & & 4 & $23^{\circ} 53^{\prime} 55.5^{\prime \prime} \mathrm{S} 46^{\circ} 23^{\prime} 22.7^{\prime \prime} \mathrm{W}$ \\
\hline Cascalho de Cima River & Casc Cima & 178 & 1 & $23^{\circ} 54^{\prime} 41.5^{\prime \prime S} 46^{\circ} 24^{\prime} 22.3^{\prime \prime W}$ \\
\hline & & 170 & 4 & $23^{\circ} 54^{\prime} 47.0^{\prime \prime} \mathrm{S} 46^{\circ} 24^{\prime} 24.4^{\prime \prime} \mathrm{W}$ \\
\hline Cascalho de Baixo River & Casc Baixo & 197 & 1 & $23^{\circ} 54^{\prime} 16.5^{\prime \prime S} 46^{\circ} 23^{\prime} 40.6^{\prime \prime W}$ \\
\hline & & & 4 & $23^{\circ} 54^{\prime} 10.1^{\prime \prime} \mathrm{S} 46^{\circ} 23^{\prime} 40.2^{\prime \prime} \mathrm{W}$ \\
\hline Mariana River & Mariana & 255 & 1 & $23^{\circ} 57^{\prime} 10.6^{\prime \prime S} 46^{\circ} 26^{\prime} 04.0^{\prime \prime} \mathrm{W}$ \\
\hline & & & 4 & $23^{\circ} 57^{\prime} 18.0^{\prime \prime} \mathrm{S} 46^{\circ} 26^{\prime} 08.1$ '’ $\mathrm{W}$ \\
\hline Piaçabuçu River & Piacabucu* & 179 & 1 & $23^{\circ} 58^{\prime} 46.4^{\prime \prime S} 46^{\circ} 25^{\prime} 58.0^{\prime \prime} \mathrm{W}$ \\
\hline & & & 4 & $23^{\circ} 58^{\prime} 46.7^{\prime \prime} \mathrm{S} 46^{\circ} 25^{\prime} 51.7^{\prime \prime} \mathrm{W}$ \\
\hline Oueirozes River & Oueirozes* & 160 & 1 & $23^{\circ} 54^{\prime} 28.0^{\prime \prime S} 46^{\circ} 26^{\prime} 58.4^{\prime \prime} \mathrm{W}$ \\
\hline Q QUETOZES KIVET & Quentrozs & 100 & 4 & $23^{\circ} 54^{\prime} 23.0^{\prime \prime} \mathrm{S} 46^{\circ} 26^{\prime} 56.8^{\prime \prime} \mathrm{W}$ \\
\hline Maranhos River & Maranhos & 137 & 1 & $23^{\circ} 54^{\prime} 20.5^{\prime \prime S} 46^{\circ} 26^{\prime} 47.3^{\prime \prime W}$ \\
\hline & & & 4 & $23^{\circ} 54^{\prime} 23.6^{\prime \prime} \mathrm{S} 46^{\circ} 26^{\prime} 50.8^{\prime \prime} \mathrm{W}$ \\
\hline Santana River & Santana* & 242 & 1 & $23^{\circ} 56^{\prime} 14.4^{\prime \prime S} 46^{\circ} 26^{\prime} 37.5^{\prime \prime} \mathrm{W}$ \\
\hline & & & 4 & $23^{\circ} 56^{\prime} 07.3^{\prime \prime} \mathrm{S} 46^{\circ} 26^{\prime} 33.8^{\prime \prime} \mathrm{W}$ \\
\hline Branco River & Branco* & 287 & 1 & $23^{\circ} 55^{\prime} 58.3^{\prime \prime S} 46^{\circ} 27^{\prime} 22.4^{\prime \prime W}$ \\
\hline & & & 4 & $23^{\circ} 56^{\prime} 07.1^{\prime \prime} \mathrm{S} 46^{\circ} 27^{\prime} 25.8^{\prime \prime} \mathrm{W}$ \\
\hline Pompeba Wide & Pompeba & 231 & 1 & $23^{\circ} 55^{\prime} 59.0^{\prime \prime S} 46^{\circ} 25^{\prime} 19.4^{\prime \prime} \mathrm{W}$ \\
\hline & 1 - & & 4 & $23^{\circ} 55^{\prime} 51.5^{\prime \prime} \mathrm{S} 46^{\circ} 25^{\prime} 18.9^{\prime \prime} \mathrm{W}$ \\
\hline Barreiros Channel & Barreiros & 132 & 1 & 235ㄱ'55.6"S 46²5’26.1"W \\
\hline & & & 4 & $23^{\circ} 57^{\prime} 54.2^{\prime \prime} \mathrm{S} 46^{\circ} 25^{\prime} 30.5^{\prime \prime} \mathrm{W}$ \\
\hline
\end{tabular}

Information was obtained from the parcels as to the structure of the stands - from the tree trunk's diameter at breast height $(\mathrm{DBH})$, height and number of individuals. All trees taller than $1.3 \mathrm{~m}$ were measured, including those with DBH of less than $2.5 \mathrm{~cm}$. The basal area was calculated from the DBH (CINTRÓN AND SCHAEFFER-NOVELLI, 1984). Measurements of phytosociological variables were made from March 9 to May 12, 2006.

Based on the phytosociological data, two indices were obtained regarding the structural development of the forest: the Importance Value Index (IVI) (CURTIS, 1959), which considers the structural importance of species in different stands, and the Complexity Index (CI) (HOLDRIDGE et al., 1971), which quantitatively summarizes the structural complexity of vegetated environments. To calculate this index, only trees with a DBH greater than $2.5 \mathrm{~cm}$ were considered. The data were computed for areas of 0.1 ha as a product of the average number of species at four sites on each transect, of the density, basal area and height (average of the three largest trees at each site, according to CINTRON AND SCHAEFFERNOVELLI, 1983), divided by 1000.

The monthly litter production was estimated between January 2006 and January 2007. For this, 240 collector baskets $(80 \times 80 \mathrm{~cm})$ with $2 \times$ 
$2 \mathrm{~mm}$ mesh were positioned $1.5 \mathrm{~m}$ above the substrate, under the canopy. The baskets were placed on $30 \mathrm{~m}$ transects parallel to the water line centered on each site. On this transect, three points were randomly selected for the placement of the baskets. Once collected, the litter was oven dried $\left(70^{\circ} \mathrm{C}\right.$ for 72 hours) and weighed. The litter data given in this paper are analyzed only in terms of spatial variability and do not include the weight of wood.

Samples for grain size determination were obtained from the substrate surface with a shovel $(0.5 \mathrm{~L})$ at the sites "edge", "lower-middle" and "landward" along ten transects (see Table 1), chosen randomly. Analysis was performed in accordance with Suguio (1973), and the mean grain size is presented on the $\Phi$ (phi) scale (- $\log _{2}$ diameter)

The phytosociological data were compared between positions in stands using ANOVA (One Way) and at the same positions between transects. The litterfall was also compared between positions in stands. Tukey's a posteriori test was applied when significant differences were found in the ANOVA, in order to highlight differences between sites. Linear regressions were applied to the phytosociological descriptors of the four parcels, to assess the presence or absence of a structural gradient.

\section{RESULTS}

At the 80 sites studied, a total of 3,870 individuals were identified belonging to three species: Rhizophora mangle, Laguncularia racemosa and Avicennia schaueriana. The average structural data are presented in Table 2.

No significant difference was found in the occupation of the substrate according to the distance from the water whether in terms of density, height or basal area of trees (Fig. 2).
Regression analysis applied to each site relative to the phytosociological descriptors shows linear fit only for height and just for 2 of the 20 sampled stands (Pedreira and Jurubatuba). At Pedreira, the gradient is towards shorter trees on the fringe and at Jurubatuba the reverse.

The comparison of the phytosociological descriptors of the species shows that the average densities of $R$. mangle and A. schaueriana are statistically equal and higher than that of $L$. racemosa (Table 3 ). It was found that the average height of $R$. mangle was lower than that of $A$. schaueriana and this was still less than that of $L$. racemosa. The average height of this latter species was also greater than that of $R$. mangle (Table 3 ).

The largest tree measured was an $A$. schaueriana, being $14.3 \mathrm{~m}$ tall (at Pompeba).

Statistically the basal area of $R$. mangle is less than that of A. schaueriana and is also smaller than that of $L$. racemosa. This latter species shows a larger basal area than A. schaueriana (Table 3).

The statistical tests show no significant difference in density and height for each tree species as between sites (Table 4). In respect to the basal area however, it is noteworthy that the sites edge" and "landward" are similar, while sites lowermiddle" and "upper-middle" may be similar or otherwise.

No significant difference was observed in density between $R$. mangle and A. schaueriana at any of the sites (Table 5). The density of $L$. racemosa was always lower than that of $R$. mangle and also lower than A. schaueriana at the edge and in the lower-middle regions.

Regarding height, there are no differences between the three species at any of the sites (Table 5). With respect to the basal area, it was found that $R$. mangle and A. schaueriana have equal values with the exception of site "lower-middle" (where the value is statistically lower for A. schaueriana). At site "upper-middle", $R$. mangle had a higher value than $L$. racemosa and at site "landward", $A$. schaueriana had a higher value than $L$. racemosa.

Table 2. Structural descriptors for the Santos Estuary mangrove forest: general average of the stands, maximum average and minimum average values.

\begin{tabular}{cccc}
\hline \hline Descriptor & $\begin{array}{c}\text { General average of } \\
\text { the stands }( \pm \mathrm{sd})\end{array}$ & $\begin{array}{c}\text { Maximum value of } \\
\text { average (stands) }( \pm \mathrm{sd})\end{array}$ & $\begin{array}{c}\text { Minimum value of } \\
\text { average (stands) }( \pm \mathrm{sd})\end{array}$ \\
\hline $\begin{array}{c}\text { Density } \\
\text { (trees/0.1ha) }\end{array}$ & $483.8 \pm 161.9$ & $797.5 \pm 353.0$ & $227.5 \pm 184.1$ \\
Height $(\mathrm{m})$ & $4.64 \pm 0.87$ & $6.12 \pm 2.54$ & $3.37 \pm 2.23$ \\
$\begin{array}{c}\text { Basal area } \\
\left(\mathrm{m}^{2} / 0.1 \text { ha) }\right.\end{array}$ & $1.47 \pm 0.28$ & $1.93 \pm 0.47$ & $1.06 \pm 0.30$ \\
Complexity index & $12.7 \pm 6.2$ & 22.2 & 4.6 \\
\hline
\end{tabular}



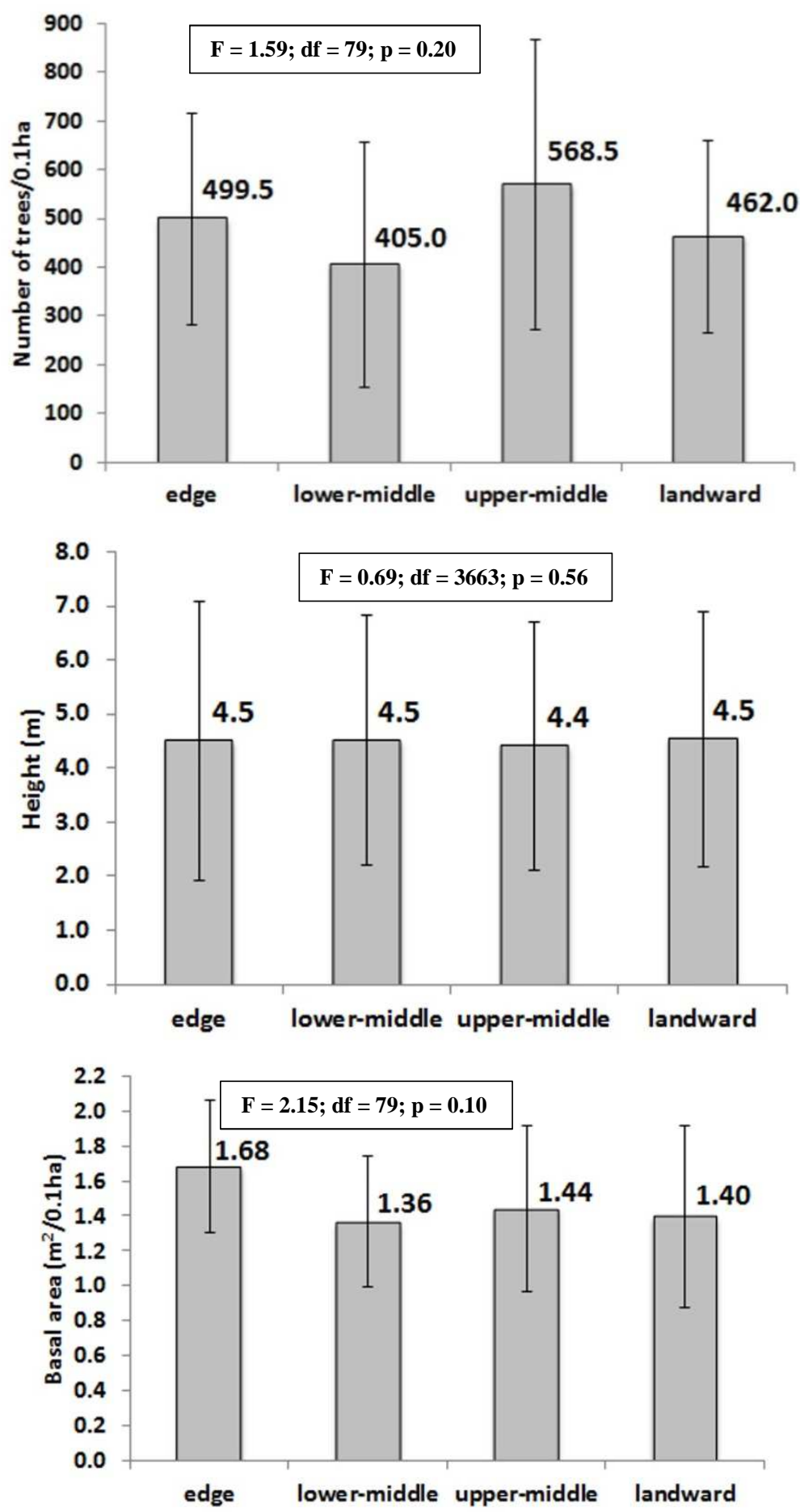

Fig. 2. Number of trees (upper figure), height (center figure) and basal area (lower figure) in each of the sites. The lines correspond to the standard deviation. In the text box are the ANOVA results for the four sites. 
Table 3. Mean tree density, mean height, basal area, relative density, dominance and frequency and importance value index (IVI) for each species of the Santos estuary mangrove forest.

\begin{tabular}{|c|c|c|c|c|c|c|c|}
\hline SPECIES & $\begin{array}{c}\text { MEAN } \\
\text { TREE } \\
\text { DENSITY } \\
\text { (trees/0.1ha) }\end{array}$ & $\begin{array}{l}\text { MEAN } \\
\text { HEIGHT } \\
\left(\mathrm{m}^{2} / 0.1 \text { ha }\right)\end{array}$ & $\begin{array}{c}\text { BASAL } \\
\text { AREA } \\
\left(\mathrm{m}^{2} / 0.1 \mathrm{ha}\right)\end{array}$ & $\begin{array}{l}\text { RELATIVE } \\
\text { DENSITY }\end{array}$ & $\begin{array}{l}\text { RELATIVE } \\
\text { DOMINANCE }\end{array}$ & $\begin{array}{l}\text { RELATIVE } \\
\text { FREQUENCY }\end{array}$ & IVI \\
\hline R. mangle & $248.0 \pm 197.1$ & $4.04 \pm 2.40$ & $0.54 \pm 0.50$ & 48.7 & 36.6 & 95.0 & 180.3 \\
\hline A. schaueriana & $214.4 \pm 208.1$ & $4.91 \pm 2.45$ & $0.71 \pm 0.58$ & 41.6 & 48.1 & 93.8 & 183.4 \\
\hline L. racemosa & $57.1 \pm 66.6$ & $5.48 \pm 2.13$ & $0.22 \pm 0.30$ & 9.7 & 15.3 & 82.5 & 107.5 \\
\hline
\end{tabular}

Table 4. Tree density, tree height, and basal area at each site for the three tree species with the ANOVA results, where 1, 2, 3 and 4 in column site differences mean "edge, "lower middle, "upper middle" and landward" respectively. *Statistical analysis by Tukey test.

\begin{tabular}{|c|c|c|c|c|c|c|c|c|c|}
\hline \multirow{2}{*}{ Descriptor } & \multirow{2}{*}{ Species } & \multicolumn{4}{|c|}{ Sites } & \multirow{2}{*}{$\begin{array}{c}\mathrm{F} \\
\text { calculated }\end{array}$} & \multirow{2}{*}{ df } & \multirow{2}{*}{$p$ value } & \multirow{2}{*}{$\begin{array}{c}\text { site } \\
\text { differences* }\end{array}$} \\
\hline & & edge & lower middle & upper middle & land-ward & & & & \\
\hline \multirow{3}{*}{$\begin{array}{l}\text { Tree density } \\
\text { (trees/0.1ha) }\end{array}$} & R. mangle & $217.5 \pm 182.4$ & $205.0 \pm 162.6$ & $296.0 \pm 255.2$ & $224.0 \pm 188.6$ & 0.839 & 79 & 0.48 & - \\
\hline & A. schaueriana & $249.0 \pm 200.4$ & $168.5 \pm 227.2$ & $209.5 \pm 218.7$ & $177.0 \pm 190.2$ & 0.608 & 79 & 0.61 & - \\
\hline & L. racemosa & $33.0 \pm 32.1$ & $31.5 \pm 37.7$ & $63.0 \pm 92.6$ & $61.0 \pm 72.0$ & 1.461 & 79 & 0.23 & - \\
\hline \multirow{3}{*}{ Height (m) } & R. mangle & $4.49 \pm 2.55$ & $4.58 \pm 1.74$ & $5.06 \pm 2.69$ & $4.25 \pm 1.81$ & 0.454 & 75 & 0.72 & - \\
\hline & A. schaueriana & $5.24 \pm 1.61$ & $5.58 \pm 1.77$ & $5.21 \pm 1.88$ & $4.98 \pm 1.13$ & 0.419 & 74 & 0.74 & - \\
\hline & L. racemosa & $5.81 \pm 1.56$ & $5.78 \pm 2.15$ & $5.52 \pm 1.65$ & $4.88 \pm 1.95$ & 0.923 & 66 & 0.43 & - \\
\hline \multirow{3}{*}{$\begin{array}{l}\text { Basal Area } \\
\left(\mathrm{m}^{2} / 0.1 \mathrm{ha}\right)\end{array}$} & R. mangle & $0.561 \pm 0.514$ & $0.920 \pm 0.584$ & $0.304 \pm 0.387$ & $0.622 \pm 0.413$ & 5.032 & 72 & 0.003 & $2 \neq 3$ \\
\hline & A. schaueriana & $0.681 \pm 0.539$ & $0.196 \pm 0.216$ & $0.548 \pm 0.483$ & $0.670 \pm 0.557$ & 3.802 & 73 & 0.014 & $1 \neq 2 ; 2 \neq 4$ \\
\hline & L. racemosa & $0.320 \pm 0.323$ & $0.541 \pm 0.584$ & $0.737 \pm 0.617$ & $0.269 \pm 0.320$ & 3.295 & 69 & 0.026 & $3 \neq 4$ \\
\hline
\end{tabular}

Table 5. p value (Tukey's test) of comparison between the three species' descriptors for the four sites. $\mathrm{RM}=$ Rhizophora mangle, $\mathrm{AS}=$ Avicennia schaueriana, $\mathrm{LR}=$ Laguncularia racemosa.

\begin{tabular}{cccccccc}
\hline \hline & & \multicolumn{2}{c}{ Density (trees/0.1ha) } & \multicolumn{2}{c}{ Height $(\mathrm{m})$} & \multicolumn{2}{c}{ Basal Area $\left(\mathrm{m}^{2} / 0.1\right.$ ha $)$} \\
\cline { 3 - 7 } & & AS & LR & AS & LR & AS & LR \\
\hline \multirow{2}{*}{ Edge } & RM & 0.803 & 0.002 & 0.483 & 0.116 & 0.736 & 0.295 \\
& AS & & 0.000 & & 0.663 & & 0.071 \\
Lower-middle & RM & 0.759 & 0.004 & 0.265 & 0.153 & 0.000 & 0.069 \\
& AS & & 0.027 & & 0.948 & & 0.107 \\
Upper-middle & RM & 0.369 & 0.002 & 0.976 & 0.789 & 0.321 & 0.034 \\
& AS & & 0.064 & & 0.897 & & 0.506 \\
Landward & RM & 0.625 & 0.006 & 0.401 & 0.506 & 0.945 & 0.054 \\
& AS & & 0.065 & & 0.982 & & 0.025 \\
\hline
\end{tabular}

A comparison between the total density and the densities of species among different stands shows a marked variation (Fig. 3) in the density of trees and species. The total density varies by almost $400 \%$ between Barnabé (minimum) and Neves (maximum). In the majority of the stands (11) $R$. mangle was the most abundant species, especially in Queirozes, where it represents $92.6 \%$ of the trees. A. schaueriana was the most abundant in seven stands, as in Mariana (91.0\% of the trees) and Piaçabuçu (78.0\% of trees). The maximum density of $L$. racemosa $(31.0 \%)$ was observed in Piaçaguera.

The average height varied significantly among stands, as indicated by Figure 4. The tallest height (Queirozes) is $55.1 \%$ higher than the lowest (Pedreira).
The basal area of tree species at the various sites studied varied significantly, as indicated by Figure 5.

The contribution of each species to total basal area is quite variable, and $A$. schaueriana presents the highest contribution in 10 stands (maximum in Barnabé); $R$. mangle presents the highest contribution in eight stands (maximum in Queirozes), whereas the highest contribution of $L$. racemosa occurred only in two stands (maximum in Barreiros). In Duas Barras, it is noteworthy that almost $90 \%$ of the basal area is composed of $A$. schaueriana. In percentage terms, $R$. mangle also presents the highest contribution in Queirozes $(81.4 \%)$. The largest percentage of contribution of L. racemosa is also in Barreiros, with $54.0 \%$. 
The IVI shows similar values for $R$. mangle and A. schaueriana and a substantially lower one for L. racemosa (Table 3).

At the level of the stand, IVIs are shown in Figure 6. This figure shows that the seven stands where the IVI is higher for $R$. mangle are located in inner regions of the watercourses, while the stands with the highest IVI for A. schaueriana are located on the wider channels, in more central areas of the system.

The Complexity Index (Table 2 and Fig. 7) shows a distribution of more complex stands in scattered locations in the system, interspersed with stands with characteristics of intermediate or low complexity.

As observed for the phytosociological descriptors, there was no significant difference in litterfall relative to the distance from water (Fig. 8).

The grain size analysis showed that the sediment typically consisted of fine silt. $(\Phi=$ $6.47 \pm 1.02$ or $\varnothing=0.011 \mathrm{~mm}$ ) (Table 6 ).

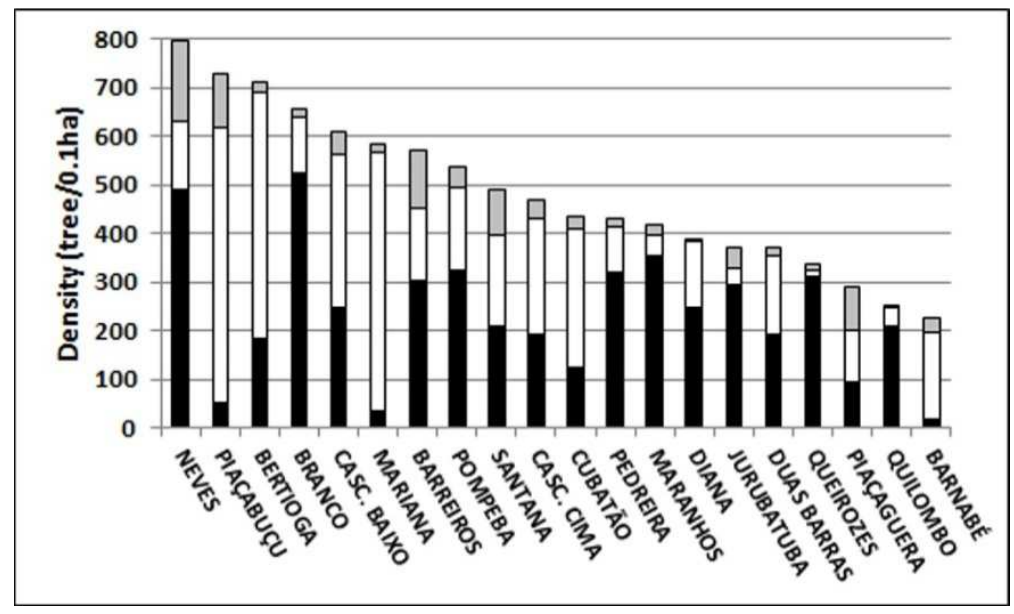

Fig. 3. Mean density of the three mangrove species found in the Santos estuary. $R$. mangle in black, L. racemosa in gray and A. schaueriana in white.

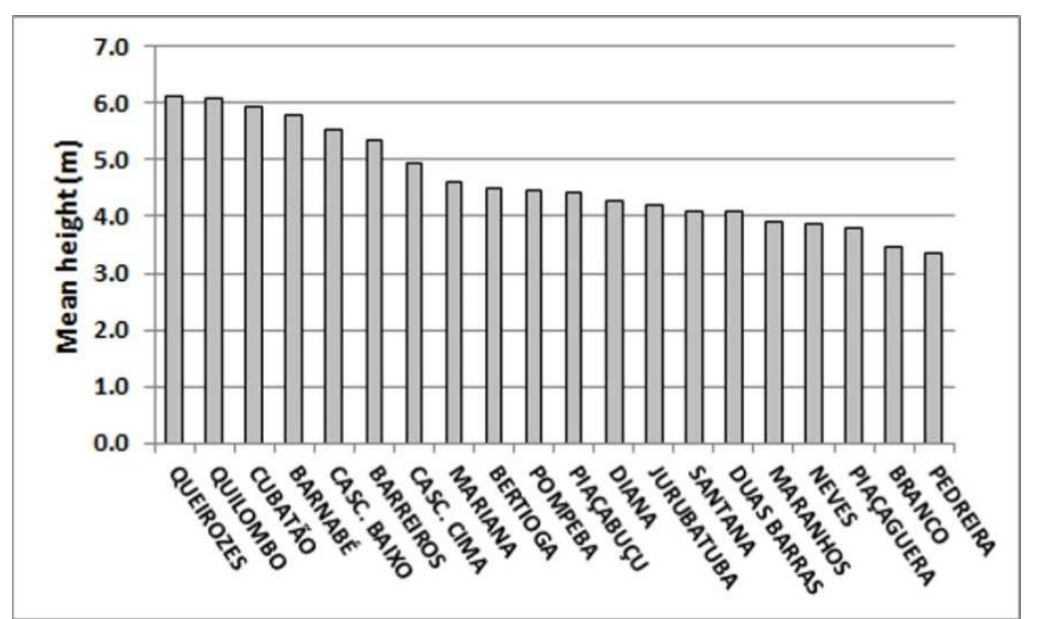

Fig. 4. Mean height for each local studied at Santos estuarine system. 


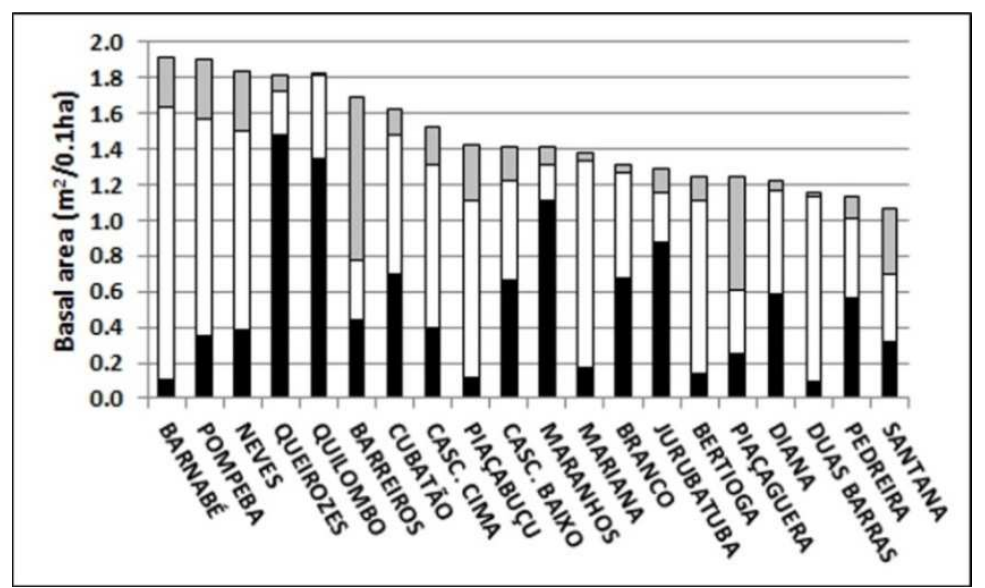

Fig. 5. Basal area of the three species, for each local study sites in the Santos estuary. $R$. mangle in black, L. racemosa in gray and A. schaueriana in white.

The grain size revealed significant differences between the three sites analyzed $(1,2$ and 4). The value of $\Phi$ of site $4(5.74 \pm 1.12)$ is smaller than those of sites $1(6.76 \pm 0.79)$ and 2
$(6.90 \pm 0.75)$, indicating that the sediment in the innermost regions has the largest grain size, since $\Phi$ is inversely proportional to the diameter of the grain.

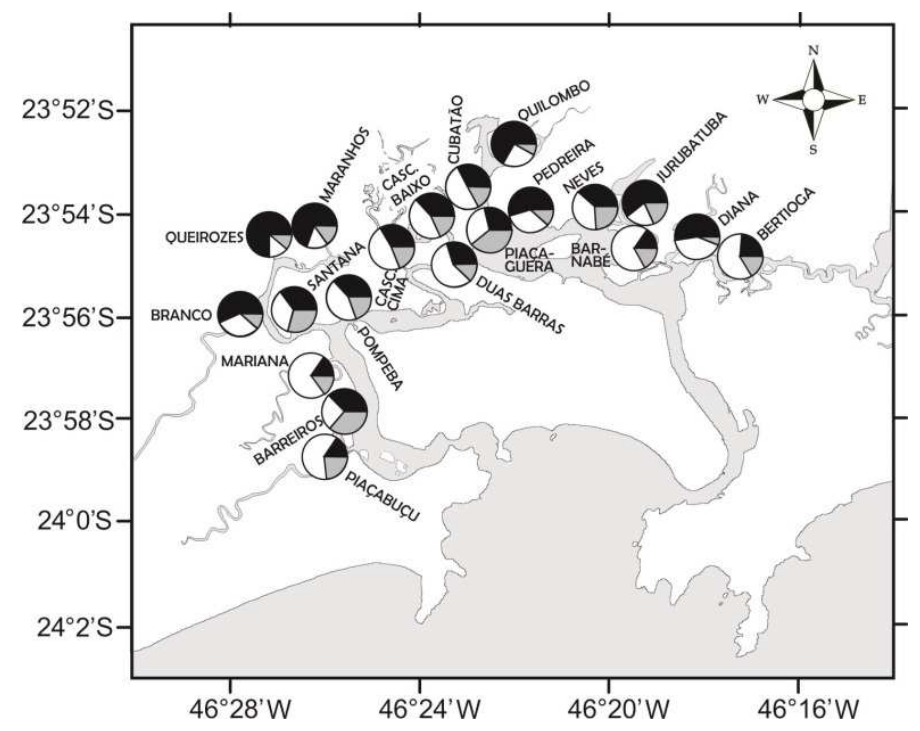

Fig. 6. Index of Value of Importance (IVI) distribution in the Santos estuary. $R$. mangle in black, L. racemosa in gray and A. schaueriana in white. 


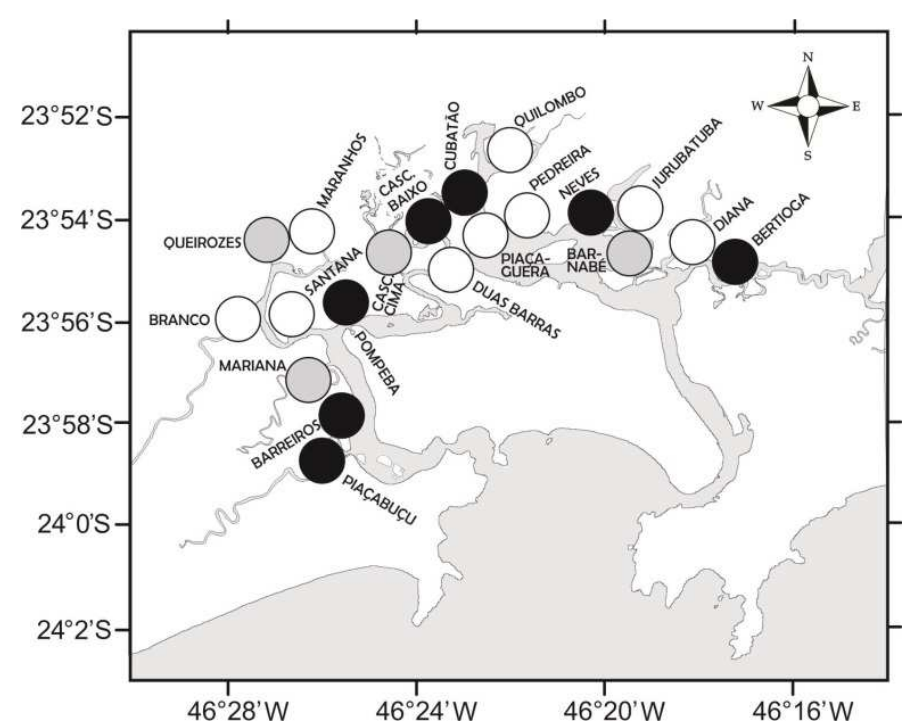

Fig. 7. Complexity Index of mangroves of the Santos estuarine system divided in three arbitrary categories: $\leq 10$, white, $>10$ and $\leq 18$, gray and $>$ 18 black.

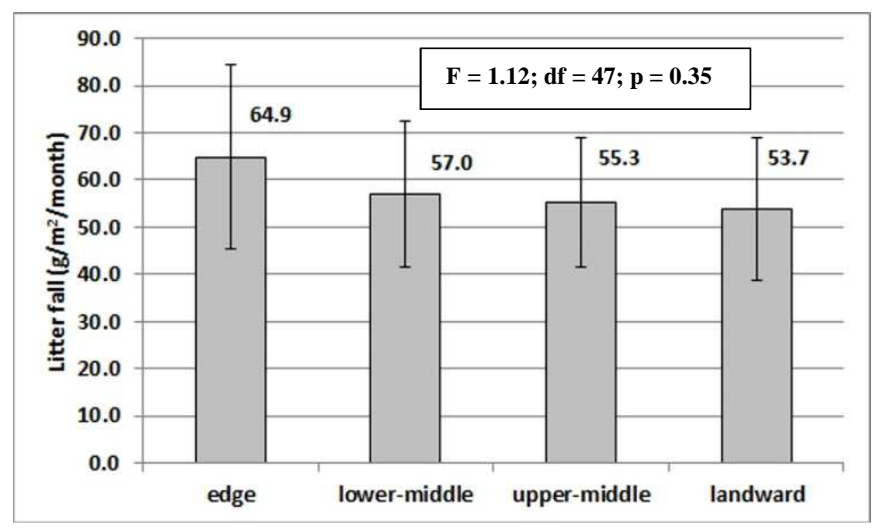

Fig. 8. Mean litterfall in each of the sites. The vertical lines correspond to the standard deviation. In the text box are the ANOVA results for the four sites.

Table 6. Grain size [Phi $(\Phi)]$ of the sediments of ten transects in the Santos estuary.

\begin{tabular}{lcc}
\hline \hline & Mean & SD \\
\hline PIAÇABUÇU & 7.18 & 0.64 \\
BRANCO & 6.57 & 1.33 \\
SANTANA & 6.73 & 1.06 \\
QUILOMBO & 6.17 & 0.32 \\
PIAÇAGUERA & 4.99 & 1.12 \\
QUEIROZES & 6.59 & 0.72 \\
BARNABÉ & 5.65 & 0.29 \\
NEVES & 7.31 & 0.21 \\
DIANA & 6.31 & 1.60 \\
PEDREIRA & 7.15 & 0.06 \\
Mean & 6.47 & 1.02 \\
\hline
\end{tabular}

\section{DISCUSSION}

The Santos estuary has historically suffered from a plethora of environmental impacts, which resulted in the environmental agency (CETESB) conducting a study focusing on the structure of the mangrove fringes. Table 7 compares the fringe data of the present study with those obtained by CETESB (1988); both studies took only trees with $\mathrm{DBH}>2.5 \mathrm{~cm}$. into consideration. 
Table 7. Phytosociological fringe data of the Santos estuary mangrove forest (trees with $\mathrm{DBH}>2.5 \mathrm{~cm}$ ). The bottom line is the $p$ value of Tukey's test for comparing the two studies*

\begin{tabular}{cccccc}
\hline \hline Study period & $\begin{array}{c}\text { Average density } \\
(\text { trees/0.1ha })( \pm \mathrm{sd})\end{array}$ & $\begin{array}{c}\text { Average height } \\
(\mathrm{m})( \pm \mathrm{sd})\end{array}$ & $\begin{array}{c}\text { Average basal area } \\
\left(\mathrm{m}^{2} / 0.1 \mathrm{ha}\right)( \pm \mathrm{sd})\end{array}$ & Number of sites & Reference \\
\hline $1982-1984$ & $182.5 \pm 80.7$ & $8.4 \pm 1.8$ & $1.09 \pm 0.54$ & 52 & CETESB (1988) \\
$2005-2006$ & $309.5 \pm 193.0$ & $6.5 \pm 2.2$ & $1.68 \pm 0.38$ & 20 & Present study \\
& $\mathrm{p}=0.0003$ & $\mathrm{p}=0.0003$ & $\mathrm{p}=0.0003$ & &
\end{tabular}

*The Bertioga Channel data set from CETESB (1988) was not used in this table, since the present study considered only one site in this channel.

These results indicate a $60 \%$ increase in the average density, a $23 \%$ reduction in average tree height and $65 \%$ increase in the average basal area of trees on the fringe of the stands, over a 25 -year period. The sites were not exactly the same but since both surveys included a large number of samples, ANOVA and Tukey tests were applied and indicated significant differences for the three descriptors. Therefore, the data denote a trend of change in the phytosociological characteristics of the fringe. This trend indicates a relatively recent occurrence of new plants on the fringe, since the average density and basal area increased, but the average height was reduced as a consequence of the large number of young plants that were established and had not yet reached maturity.

Accordingly, the results of the present study could be indicative of the recovery of the mangrove fringe, which may be occurring as a consequence of the implementation and enforcement of environmental legislation, advances in control and monitoring by environmental agencies, introduced in 1984 (CETESB, 2001). However, despite the large number of randomly selected stands studied here, the visual inspection of mangroves throughout the channels allowed for the identification of poorly developed stretches of stands, apparently under some kind of stressor, which may be of anthropogenic origin. However, to check the actual recovery of the mangrove stands requires a systematic study of the forests over time in order to determine whether there is actually an increase in height over time, since the presence of any stressing agents as described for the region (CETESB, 2001) may prevent the full development of the forests.

Regarding the different stands in the region studied, significant structural variation was found among them. This heterogeneity does not only occur in the Santos estuarine system mangroves often exhibit great variability in their structural and functional characteristics (LUGO AND SNEDAKER, 1974, POOL et al., 1977).

As previously described, a common feature of the mangrove system is the zonation of vegetation due to the environmental gradient. Thus the portions closest to the water are subject to further processes of estuarine origin, whereas portions more distant from the water are mostly subject to processes of atmospheric origin, such as precipitation and evapotranspiration, and variations in the drainage due to the topography. BALL (1980) emphasizes that the ground above the high water mark is subject to extreme conditions, periods of water saturation alternating with desiccation, with wide fluctuations of salinity, but that below that level the conditions are considered more stable.

However, many forests do not show zonation, as verified by Smith III (1992) in a comprehensive review on this subject. Also SCHAEFFER-NOVELLI et al. (1990), describing the mangrove forests of Cananéia (about $250 \mathrm{~km}$ south of our study area), suggest that this gradient does not develop in all stands.

Thus, even with great competition for the same resources as is the case of mangrove trees, the coexistence of these species is possible even without niche differentiation, such that even if interspecific competition affects the abundance of populations, it does not necessarily determine the composition of species in the community (ATKINSON AND SHORROCKS, 1981). In many populations, the partitioning of resources associated with interspecific competition does not seem to structure the community. Studies with plants involving taxa as diverse as phytoplankton and trees (BROKAW AND BUSING, 2000) similarly do not show consistent evidence to support a strong role for niche partitioning in promoting coexistence and species diversity. The data obtained in the present study indicate no selectivity of the three species of trees according to the distance from the water, illustrating that the interspecific competition among them is not sufficient to translate into niche differentiation. In spite of the lack of bathymetry data, we can say that the substrate slope is very small, since the tidal amplitudes in the estuary vary from 0.14 to $0.60 \mathrm{~m}$ (HARARI AND CAMARGO, 
$1995)$ and the width of the mangrove forest ranged between 117 and $280 \mathrm{~m}$ on the transects studied.

In the Cananéia mangrove forests, SCHAEFFER-NOVELLI et al. (1990) and CUNHA-LIGNON et al. (2011) found zonation of species. According to those authors, the stability of each site must be the main factor responsible for differences between forest types.

The present data on the mangrove forests of Santos exhibit homogeneity of both the phytosociological structure and species distribution in regard to environmental gradients, i.e. the distance from the water. The Santos mangrove forest has developed around numerous sinuous channels, which tends to reduce the speed of water flow, thereby reducing the energy subsidy, favoring the stability of the slopes of the channels, where depositional processes dominate in the innermost areas of the estuary. The port channel, for instance, needs continual dredging to prevent silting up. The lowest water balance average in Santos is positive and greater than $50 \mathrm{~mm}$ (August) and the average annual rainfall in Santos is high: $3207 \mathrm{~mm}$ (EMBRAPA, 2012). These environmental characteristics are such that the haline stress in the basins of the regions is probably small, explaining the lower structural variability observed in the mangrove forests studied.

The analysis of the IVI shows higher values for $R$. mangle in stands with riverine influence, such as Jurubatuba, Diana, Pedreira, Quilombo, Maranhos, Queirozes and Branco; exceptions to this pattern occurred only in Mariana and Piaçabuçu, where A. schaueriana has higher IVI, but these stands are located closer to the main channel of the estuary, possibly with a higher contribution of seawater than those previously cited. Several authors have postulated that $R$. mangle is a species less tolerant of salt (SCHAEFFERNOVELLI, 1995) thus explaining its prevalence in areas with a higher fresh water contribution.

According to several authors (TOMLINSON, 1986; SOARES, 1999), $L$. racemosa is a typical species of degraded stands undergoing a process of regeneration, characterized as a pioneer species in a process of secondary succession.

Following Smith III (1992), mangrove forests subject to frequent disturbances have a smaller representation of Rhizophoraceae than of $L$. racemosa. In the Santos mangrove forests, singularly, L. racemosa features low density, basal area and IVI similar to Cananéia mangroves, which is considered a more pristine area. Moreover, the sediment composition of the mangroves of the Santos estuary is predominantly silt, which seems to be unfavorable to the development of $L$. racemosa, according to CINTRON AND SCHAEFFERNOVELLI (1983).

The structural development of mangrove forests is generally regarded as an indicator of their degree of maturity (CINTRON AND SCHAEFFER-NOVELLI, 1985). However, several authors consider that this is not always true because of competitive interactions and environmental factors (CHEN AND TWILLEY, 1999).

Apparently there is no clear pattern for the distribution of stands according to the CI. High values of CI may occur in areas with distinct degrees of hydrodynamics or intake of salt water. A stand can have a relatively high value of CI and present intermediate values in the descriptors - as at Bertioga and Casc. Baixo.

The measure of litterfall production represents useful data to describe the function of this ecosystem and to estimate the impact of a variety of environmental regimes (POOL et al. 1975). Several authors (CINTRON AND SCHAEFFER-NOVELLI, 1985, TWILLEY et al., 1986; DAY JR. et al., 1987, 1996) emphasize that the fringe areas tend to produce higher litterfall. One reason for the reduced production as the water distance increases is the saline stress, which is usually found along the flooding gradient (TWILLEY et al. 1986, HUTCHINGS AND SAENGER, 1987). However, the present data indicated no statistical difference with distance from the water, which can be explained as due to the same cause as that given for the absence of structural and species zonation, i.e. low energy of currents at the stations sampled resulting from the great sinuosity of the channels and low haline stress in the basins due to the high rainfall and hydric excess throughout the year.

VANNUCCI (1999) reports that the physical characteristics of the soil seem to have the same importance as its chemical properties in determining the growth and health of mangroves. The differences in the sizes of the grains analyzed were very small, all within the category of silt, by the Wentworth scale, which also helps explain the absence of structural zonation of species and litterfall production in respect to the distance from water.

High levels of contamination have been reported for the sediment of the Santos region (CETESB, 2001; HORTELLANI et al. 2008), including of that by heavy metals, which can interfere with many metabolic processes, preventing the full development of the plant (SIEDLECKA, 1995). On this basis, it is possible to attribute the poor development of some mangrove stands in the Santos region to stressors of anthropogenic origin 
that overlap with the natural forcings, as reported by OLIVER AND LARSON (1990).

The architecture of the stands is the result of interaction between the growth characteristics of trees, their physiological requirements and environmental constraints that operate on the system, such forcings need not, however, be only natural, as pointed out by SOARES et al. (2003) when describing the factors determining the structure of mangrove forests in Guanabara Bay (Rio de Janeiro State). The authors attribute the high structural diversity observed to anthropogenic disturbances, and the variability observed is due to the variations in the nature, characteristics, spatial and temporal variability of the disturbances faced by the resilience of the system. The low number of stands with full mature stand characteristics (only three) indicates that the environment is still subject to stressors, although the comparison with data from about 25 years ago shows a trend to recovery in the area. As emphasized by EVERHAM AND BROKAW (1996), natural disturbances combined with anthropogenic disturbances can cause enough changes in structure and function to lead to an altered steady state due to the high metabolic demands associated with growth and reproduction, particularly when ecosystems experience frequent overlapping disturbances.

\section{ConCLuSION}

The results of this study demonstrate a structural diversity of forests, but also an absence of zonation by species, phytosociological features, and litter production in the mangrove forests of the Santos estuarine complex. This characteristic may be attributed to several factors: 1 - the low energy subsidy that occurs as a function of the microtidal regime and by virtue of the reduction in the velocity of the water in the inner regions of the system as a consequence of the sinuosity of the channels; 2 - the sediment grain size is quite homogeneous and consists of a predominance of silt across the area, confirming the classification of the region as a depositional with low hydrodynamic energy; 3 - the absence of any water deficit in the region reduces the haline gradient within the basin; 4 - comparison with past data concerning the mangrove fringe indicates a trend towards the recovery of the stands, a possibility which would require further monitoring to confirm; 5 - the region has historically suffered a wide variety of anthropogenic impacts, which may be preventing the full development of mangroves, as suggested by the phytosociological analysis, which characterizes the region as consisting mainly of stands with features of immaturity.

\section{ACKNOWLEDGEMENTS}

We wish to thank M.Sc. João A. P. dos Santos for his substantial help with the fieldwork and Dr. Roberto P. Borges for his help with the statistical analysis. We are also grateful to Dr. Ramiro Neves (Maretec/IST -Lisboa/Portugal), who conceived the Ecomanage Project and to the European Commission's Six Framework Programme - Contract $n^{\circ}$ INCO-CT-2004-003715 for financial support.

\section{REFERENCES}

ATKINSON, W. D. AND SHORROCKS, B. 1981. Competition on a divided and ephemeral resource: a simulation model. Journal of Animal Ecology, v. 50, p.461-471, 1981.

BALL, M. C. 1980. Patterns of secondary succession in a mangrove forest of southern Florida. Oecologia, v.44, p.226-235, 1980.

BROKAW, N. AND BUSING, R. T. Niche versus chance and tree diversity in forest gaps. Trends in Ecology and Evolution, V. 15, p.183-188, 2000.

CETEC. Minuta preliminar do relatório de situação dos recursos hídricos da UGRHI7. Comitê da Bacia Hidrográfica da Baixada Santista. Relatório Zero, 2000. 238p. Disponível em: http://www.sigrh.sp.gov.br/sigrh/ARQS/RELATORI O/CRH/CBH-BS/218/relbsseg.pdf. Acesso em: Mar. 2012.

CETESB. Estudo dos manguezais da Baixada Santista. Relatório Final. São Paulo: CETESB, 1988. 70p.

CETESB. Sistema estuarino de Santos e São Vicente. Procop: Programa de Controle de Poluição, Programa de Assistência Técnica, 2001. 141p. Disponível em: http://www.cetesb.sp.gov.br/userfiles/file/laboratorios/ publicacoes/relatorios/rel_sist_estuarino/relatorio.zip Acesso em: Mar. 2012.

CHAPMAN, V. J. Mangrove biogeography. In: WALSH, G. E.; SNEDAKER, S. C.; TEAS, H., (eds.) Proceedings of International Symposium on Biology and Management of Mangroves. Gainesville, FL: Institute of Food and Agricultural Sciences, University of Florida, 1975. p. 3-22.

CHEN, R. AND TWILLEY, R. R. Patterns of mangrove forest structure associated with soil nutrient dynamics along the Shark River estuary. Estuaries, v. 22, p.1027-1042, 1999.

CINTRÓN, G. AND SCHAEFFER-NOVELLI, Y. Introducción a la ecologia del manglar. Oficina Regional de Ciencia y Tecnologia de Ia UNESCO para a America Latina y el Caribe - ROSTLAC. Montevideo-Uruguay, 1983. 109 p.

CINTRÓN, G. AND SCHAEFFER-NOVELLI, Y. Methods for studying mangrove structure. In: Snedaker, S. C \& Snedaker J. G. (eds.). The mangrove ecosystem: research methods. UNESCO, Bungay, United Kingdom, p.91-113, 1984. 
CINTRÓN, G. AND SCHAEFFER-NOVELLI, Y. Características y desarollo estructural de los manglares de Norte y Sur America. Ciencia Interamericana, v. 25, n.1-4, p.4-15, 1985

CUNHA-LIGNON, M.; COELHO Jr.; ALMEIDA, R.; MENGHINI, R. P.; SCHAEFFER-NOVELLI, Y; CINTRÓN, G. AND DAHDOUH-GUEBAS, F. Characterization of mangrove forest types in view of conservation and management: a review of mangals at the Cananéia region, São Paulo State, Brazil. Journal of Coastal Research, SI 64 (Proceedings of the 11th International Coastal Symposium), P.349$353,2011$.

CURTIS, J. T. Vegetation of Wisconsin: An ordination of plant communities. University of Wisconsin Press, $1959.657 \mathrm{p}$.

DAY Jr., J. W.; CONNER, W.; LEY-LOU, F.; DAY, R. H. AND MACHADO, A. N. The productivity and composition of mangrove forests, Laguna de Términos, México. Aquatic Botany, v. 27, p.267284, 1987.

DAY Jr., J. W.; CORONADO-MOLINA, C.; VERAHERRERA, F.; TWILLEY, R. R.; RIVERAMONROY, V. H.; ALVAREZGUILIEN, H.; DAY, R. \& CONNER, W. A 7 year record of above-ground net primary production in a southeastern Mexican mangrove forest. Aquatic Botany, v. 55, p.39-60, 1996.

EMBRAPA. Banco de dados climáticos do Brasil. 2012. Disponível em: http://www.bdclima.cnpm.embrapa.br/resultados/bala nco.php?UF=\&COD=450. Acesso em: Mar. 2012.

EVERHAM, E. M. AND N. L. BROKAW, N. L. Forest damage and recovery from catastrophic wind. The Botanical Review, 1996, v. 6, p.114-149.

HARARI, J. \& CAMARGO, R. Tides and mean sea level variabilities in Santos (SP), 1944 to 1989. Relat. int. Inst. oceanogr., v. 36, p.1-15, 1995.

HOLDRIDGE, L. R.; GRENKE, W. C.; HATHEWAY, W. H.; LIANG, T. \& TOSI, J. A. Forest environments in tropical life zones. N.Y.: Pergamon Press, 1971.747p.

HORTELLANI, M. A.; SARKIS, J. E. S.; ABESSA, D. M. S. AND SOUSA, E. C. P. M. Avaliação da contaminação por elementos metálicos dos sedimentos do estuário de Santos - São Vicente. Quim. Nova, v. 31, n.1, p.10-19, 2008.

HUTCHINGS, P. A. AND SAENGER, P. Ecology of mangroves. University of Queensland Press. Brisbane, $1987.388 \mathrm{p}$.

LEMOS, M. C. M. The politics of pollution control in Brazil: State actors and social movements cleaning up Cubatão. World Development, v. 26, n.1, p.75-87, 1998.

LUGO, A. E. AND SNEDAKER, S. C. The ecology of mangroves. Annu. Rev. Ecol. System, v. 5, p.39-64, 1974.

MARTIN, L. AND SUGUIO, K. Excursion route along the Brazilian coast between Santos (State of São Paulo) and Campos (north of State of Rio de Janeiro). International Symposium on Global Changes in South America during the Quaternary, São Paulo. Abequa, Special Publ., v. 2, p.1-136, 1989.
MENEZES, G. V.; SCHAEFFER-NOVELLI, Y; POFFO, I. R. F. AND EYSINK, G. G. J. Recuperação de manguezais: um estudo de caso na Baixada Santista de São Paulo, Brasil. Braz. J. Aquat. Sci. Technol., v.9, n.1, p.67-74, 2005.

MENGHINI, R. P., Coelho-Jr, C., Rovai A. S., CunhaLignon, M., Schaeffer-Novelli, Y AND Cintrón, G. Massive mortality of mangrove forests in Southeast Brazil (Baixada Santista, State of São Paulo) as a result of harboring activities. Journal of Coastal Research, SI 64 (Proceedings of the 11th International Coastal Symposium), p. 1793-1797, 2011.

OLIVER, C. D. AND LARSON, B. C. Forest Stand Dynamics. McGraw-Hill: NewYork, 1990. 457 p.

POOL, D. J.; LUGO, A. E. \& SNEDAKER, S. C. Litter production in mangrove forests of Southern Florida and Puerto Rico. In: WALSH, G., SNEDAKER, S. C. \& TEAS, H. (eds) Proceedings of the International Symposium on Biology and Management of mangroves. Institute of Food and Agriculture Sciences, University of Florida, v. 1, 1975. p. 213237.

POOL, D. J.; SNEDAKER, S. C. AND LUGO, A. E. Structure of mangrove forests in Florida, Puerto Rico, Mexico, and Costa Rica. Biotropica, v.9, n.3, p.195212, 1977.

PRITCHARD, D. W. What is an estuary: physical viewpoint. In: Lauf, G. H. (ed.) Estuaries. A.A.A.S. Publ. No. 83, Washington, D.C., 1967. p. 3-5.

SANTOS, E. O. 1965. Características climáticas. In: AZEVEDO, A. A Baixada Santista - Aspectos Geográficos. v. 1: As Bases Físicas. São Paulo: EDUSP, 1965. p. 95-150.

SCHAEFFER-NOVELLI, Y. Perfil dos ecossistemas litorâneos brasileiros, com especial ênfase sobre o ecossistema manguezal. Publicação Especial do Instituto Oceanográfico de São Paulo, v. 7, p.1-16, 1989.

SCHAEFFER-NOVELLI, Y. Manguezal: Ecossistema entre a Terra e o Mar. Caribbean Ecological Research, São Paulo. 1995. 64p.

SCHAEFFER-NOVELLI, Y.; MESQUITA, H. S. L. AND CINTRÓN-MOLERO, G. The Cananéia Lagoon Estuarine System, São Paulo, Brazil. Estuaries, v. 13, n.2, p.193-203, 1990.

SCHAEFFER-NOVELLI, Y; CINTRÓN-MOLERO, G.; SOARES, M. L. G. AND DE-ROSA, T. Brazilian mangroves. Aquatic Ecosystem Health and Management, v. 3, p. 561-570, 2000.

SCHMIEGELOW, J. M. M.; GIANESELLA, S. M. F; SIMONETTI, C.; SALDANHA-CORRÊA, F. M. P.; FEOLI, E.; SANTOS, J. A. P.; SANTOS, M. P., RIBEIRO, R. B. AND SAMPAIO A. F. P. Primary producers in Santos estuarine system. In: NEVES, R.; BARETA, J. \& MATEUS, M. (eds). Perspective on integrated coastal zone management in South America. Lisboa: IST Press, 2008. p. 161 - 174.

SIEDLECKA, A. 1995. Some aspects of interactions between heavy metals and plant mineral nutrients. Acta Soc. Bot. Pol., v.3, p.265-272, 1995.

SMITH III, T. J. Forest structure. In: ROBERTSON, A. I AND ALONGI, D. M. (Eds.), Tropical mangrove ecosystems. American Geophysical Union, Washington, 1992. p. 101-136. 
SNEDAKER, S. C. Mangrove species zonation: why? In SEN, D .N. \& RAJPUROHIT, K. S. (eds). Contributions to the ecology of halophytes. The Hague: Dr. W. Junk (Tasks for vegetation science, 2), 1982. p. 111-125.

SOARES, M. L. G. Estrutura vegetal e grau de perturbação dos manguezais da Lagoa da Tijuca, Rio de Janeiro, RJ, Brasil. Revista Brasileira de Biologia, 1999, v. 59, n.3, p.503-515.

SOARES, M. L. G. S.; CHAVES, F. O.; CORRÊA, F. M AND SILVA JR., C. M. G. Diversidade estrutural de bosques de mangue e sua relação com distúrbios de origem antrópica: o caso da Baía de Guanabara (Rio de Janeiro). Anuário do Instituto de Geociências, v. 26, p.101-116, 2003.
SUGUIO, K. Introdução à sedimentologia. EDUSP: São Paulo, 1973. 317p

TUTIEMPO. Clima em Santos Aeroporto - Históricos El Tiempo. Disponível em: http://www.tutiempo.net/clima/Santos_Aeroporto/838 180.htm. Acesso em: Nov 2008.

TWILLEY, R. R.; LUGO, A. E. AND PATTERSONZUCCA, C. Litter production and turnover in basin mangrove forests in Southwest Florida. Ecology, v. 67, n.3, p.670-683, 1986.

VANNUCCI, M. Os manguezais e nós: uma síntese de percepções. São Paulo: EDUSP, 1999. 233p.

(Manuscript received 19 February 2013; revised 28 November 2013; accepted 22 May 2014) 